\title{
PRO-ECOLOGICAL ATTITUDES AMONG STUDENTS
}

\author{
Agata Balińska, $\mathrm{DSc}^{1 *}$; Piotr Gabryjończyk, $\mathrm{PhD}^{2 * *}$; Jan Zawadka, $\mathrm{PhD}^{3 * * *}$
}

\author{
Faculty of Economic Sciences, Warsaw University of Life Sciences - SGGW \\ ${ }^{*}$ https://orcid.org/0000-0002-8777-9955 \\ ** https://orcid.org/0000-0002-8815-9723 \\ *** https://orcid.org/0000-0003-1979-0607
}

\begin{abstract}
The aim of the study is to present the pro-ecological (i.e. favourable for ecology, acting in favour of environment) attitudes of people who study at the Faculty of Economic Sciences of the Warsaw University of Life Sciences - SGGW. The theoretical part discusses the concept and the essence of ecology and ecological awareness, as well as the elements and significance of ecological education. In the practical part, the attitude of the group of students of the Faculty of Economic Sciences at the WULS-SGGW to the necessity of pro-ecological behaviours and their expectations regarding the ways of propagating knowledge and activities in the field of environmental education is presented. It turned out that more than $90 \%$ of the respondents consider such behaviours as a necessary one, while around $60 \%$ believe that the entities responsible for promoting it among the society - in the form of obligatory education - should be schools and universities. Finally, the study contains original conclusions and findings regarding the observations made during the research.
\end{abstract}

Key words: ecological education, pro-ecological attitudes, pro-ecological behaviours, students JEL codes: Q53, Q56, Q57

\section{INTRODUCTION}

The dynamic economic development and civilization progress observed in recent decades in many countries undoubtedly contributes to improving the quality of life of their residents. Technological achievements, development of modes of transport and communication, the increasing popularity of the internet greatly simplify our lives, improve everyday tasks and even suggest how to take care of health. Unfortunately, the actions and processes that support this ever-growing welfare are, directly or indirectly, the cause of a number of problems and threats, among which there are, among others, water and air pollution, acid rains, greenhouse effect, soil degradation and finally a gigantic increase in municipal and post-production waste. The awareness of these threats and the vision of ecological disaster forces governments and numerous organizations (including global ones) to take up various pro-ecological activities carried out in the form of remedial programs and implementation of relevant regulations. A very important element increasing the effectiveness of these activities is shaping ecological awareness and dissemination of desirable attitudes and behaviours favouring the protection of the natural environment. Ecological education has an extremely

${ }^{1}$ Corresponding author: Nowoursynowska 166,02-787 Warsaw, Poland, agata_balinska@sggw.pl

${ }^{2}$ Corresponding author: Nowoursynowska 166, 02-787 Warsaw, Poland, piotr_gabryjonczyk@sggw.pl

${ }^{3}$ Corresponding author: Nowoursynowska 166,02-787 Warsaw, Poland, jan_zawadka@sggw.pl, +4822 5934154 
important role in this process. It starts already in kindergarten and primary classes. Pro-ecological values and models acquired by children during school education should evolve into specific and desirable attitudes and behaviours of people completing the stage of obligatory education. The aim of the study is therefore to present the pro-ecological attitudes of people who study at the Faculty of Economic Sciences of the Warsaw University of Life Sciences - SGGW.

\section{THE CONCEPT AND THE ESSENCE OF ECOLOGICAL EDUCATION}

The term "ecology" was introduced to science and literature in the 1860s by the German zoologist Ernst Heackel and comes from the Greek words: oikos, which means home, place of life, and logos - word, science (Haeckel, 1866; Egerton, 2013; Terlecka, 2014). Literally, therefore, the term means the science of the place of life of organisms (environment) (Friederichs, 1958; Budniak, 2009) or the department of biology examining the relationship of external conditions with the life of organisms (Budniak, 2014). In a more detailed way, the concept of ecology is defined by Houszka (2014), who claims that it is a science involving interactions between individuals of the same species, different species, as well as living organisms and abiotic factors in the environment. The domain of ecology is therefore the interaction between living organisms and the surrounding environment.

The priority factor shaping ecological awareness, pro-ecological attitudes and behaviours is ecological (also known as natural, environmental ${ }^{1}$ ) education, which should be understood as a concept of education and upbringing in the spirit of respect for the natural environment and shaping attitudes and views of the society towards the surrounding world. It concerns the awakening of sensitivity to environmental problems, searching for causes and predicting the ef- fects of phenomena leading to the degradation of the natural environment (Tuszyńska, 2006).

Parczewska (2009) presents a slightly more extensive and insightful definition of the term ecological education. Such education includes:

- providing information on the environment, its functioning, phenomena occurring in it and generally understood problems related to its degradation;

- influence on the emotional sphere of the child, sensitization to the beauty of nature, shaping proecological attitudes;

- triggering environmental and eco-development activities.

It is worth noting that in ecological education, the natural environment can be both an object, a tool, as well as a beneficiary of educational activities. The following elements can be distinguished in ecological education (Żeber-Dzikowska, 2016):

- education in the environment - the environment is used as a source of knowledge and development of the child's versatile abilities;

- education about the environment - transferring knowledge about the local and global environment and relationships between them, which aims to facilitate the understanding of the principles of the coexistence of the natural world and the human world; education about the environment is also aimed at shaping the skills of integrated recognition of the socio-natural environment;

- education for the environment - shaping the full care of the approach to the environment and instilling such values, so that everyone can feel responsible for his actions in the natural world.

Ecological education is therefore an element of upbringing, where a positive and responsible attitude to nature should become a permanent component of the value system (Strumińska-Doktór, 2007). This education cannot be limited only to the transfer of

\footnotetext{
${ }^{4}$ In the scientific literature are significant discrepancies in terms of the concepts used - there are, inter alia, ecological, environmental and sozological education. The problem was discussed in detail by Dołega (2003) or Domeracki and Tyburski (2011). Moreover, the following terms are less frequently used: education about the natural environment (Sander, 2007) and pro-ecological education (Sander, 2008). It is worth mentioning that in the National Strategy of Ecological Education, developed in 2002 by the Ministry of the Environment, due to inaccuracies in the field of terminology, the concepts of ecological education and environmental education are used interchangeably.
} 
knowledge, but should also include raising and shaping pro-ecological attitudes (Kiełczewski, 2001), which are conditioned by ecological awareness and result in appropriate behaviour.

Ecological awareness (in a rather broad sense) can be defined as the totality of ideas, values and opinions about the environment as a place of life and human development (Papuziński, 2006). The process of shaping this awareness depends on many factors, among which one can indicate the place of residence, adopted social norms or information contained in the mass media (Nycz-Wróbel, 2012). Undoubtedly, the most important role in shaping and developing ecological awareness is assigned to formal education, which task is to direct the attention of children and youth to environmental protection and to shape their positive mindset and attitudes to the natural environment (Górska, 1995). That fact was confirmed in a research made for purpose of this paper, when students stressed the role of formal educational institutions and obligatory education in process of disseminating and propagating knowledge about pro-ecological behaviours. It should also be mentioned that shaping pro-ecological attitudes (which is the result of the acquisition of appropriate knowledge and ecological sensitivity by aware man (Nowińska et al., 2014)) and a healthy lifestyle of society is one of the main goals of education for sustainable development (UNECE, 2014). The idea and the essence of this kind of development is best reflected in the title of the World Commission on Environment and Development report of 1987 “Our common future” (WCED, 1987).

\section{MATERIALS AND METHODS}

The empirical material was obtained through an reactive research, with use of a diagnostic survey as a method of data collection. The study was conducted in May 2019 with use of an online questionnaire consisting of close-ended questions. It was addressed to the students of the Faculty of Economic Sciences at the WULS-SGGW. Therefore, random and intentional selection was used in the research, as the objective of the study was to verify ecological awareness and some opinions about ecological education among the youth (who, according to Sawitri and Widiaswati
(2018), may become leaders capable of making difference in the future) of one of the national universities orientated on issues related to the environment.

In total, the study included 119 people, of whom $72 \%$ were women. The large majority of the respondents, more than $90 \%$, were full-time bachelor students, represented in $88 \%$ by students of the second and third year of studies (in similar proportions). The most numerous group of people studied in the field of "Tourism and recreation" (almost 43\%), every fifth represented "Economics" and "Logistics", while less significant rest studied "Management" and "Finance and accounting" - therefore such group cannot be claimed as a representative for the whole Faculty of Economic Sciences. Respondents came from diverse settlement units - every third one was classified in the "village" category, while slightly less numerous group was from cities over 100,000 residents. Despite this diversity, almost $90 \%$ of the respondents at the time of the research lived in the capital city (every 2 out of 3 ) or its nearest surroundings (up to $30 \mathrm{~km}$ ).

\section{RESULTS AND DISCUSSION}

Respondents, defining their own attitude in the field of pro-ecological behaviour, appeared to be divided into two almost identical in size groups $-49.5 \%$ declared themselves as consumers trying to behave proecological, others stated that they cannot be included in this group. What is interesting, however, there was much more unanimity in the research sample in terms of recognizing the need for such behaviour, as shown in Figure 1.

It turns out that over $92 \%$ of the respondents are aware of the need for such behaviour, while the percentage of other unconvinced groups is marginal. It can therefore be concluded that in terms of awareness of the importance of human behaviour towards the natural environment, those young people are well-formed and understand the importance of maintaining the balance of ecosystems in which they function. Unfortunately, it apparently does not involve active actions that may support it. However, it should be noted that such high percentage of positive answers may also be the result of greater participation of women in the sample - it has been proven that 


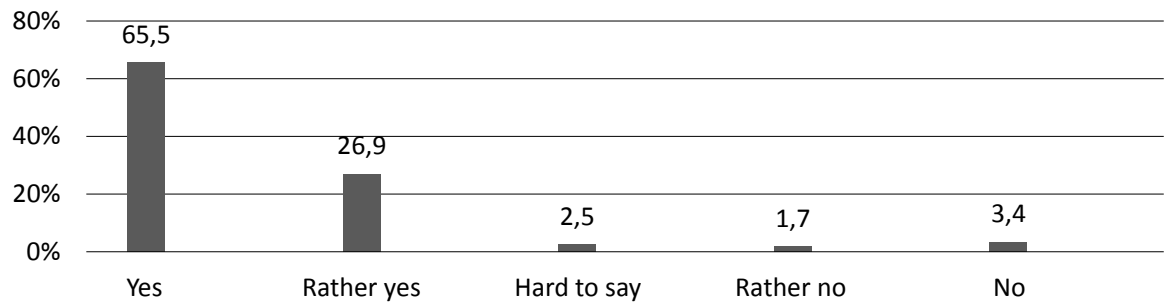

Figure 1. Necessity of pro-ecological behaviours in society in the opinion of the respondents

Source: own research.

gender influences an environmental attitude and behaviour and women are those who seem to be more likely to act environmentally friendly, regardless the economic circumstances (Zelezny, Chua and Aldrich, 2000; Vicente-Molina, Fernández-Sainz and Izagirre-Olaizola, 2013).

In connection with the above, the question arises: who should be responsible for spreading knowledge about pro-ecological behaviours and whether, in turn, the indicated entities have a chance to stimulate or even enforce real activities in this area? The distribution of respondents' answers in the first of these issues is presented in Figure 2.

The most often indicated institutions were those usually associated with the education of the society - schools and universities. Those answers therefore are consistent with theories presented by Górska (1995) and Kiełczewski (2001), who stressed the role of formal educational institutions in shaping pro-ecological attitudes. Educated people are more concerned about the environment and, at the same time, more aware of damages that mankind may cause in the world of nature (Lozano, 2006). Higher level of education usually results in better knowledge about the environment, and - consequently - in taking pro-environmental actions (Schlegelmilch, Bohlen and Diamantopoulos, 1996). Therefore answers of the surveyed students confirm fact that role of the schools and universities seems to be indispensable in the process of disseminating knowledge about pro-ecological behaviours. Nearly half of the respondents also indicated the media, probably primarily because of their potential in terms of mass impact. It is worth noting, however, that these are the entities that in the first place can mainly meet the demand for disseminating knowledge and its

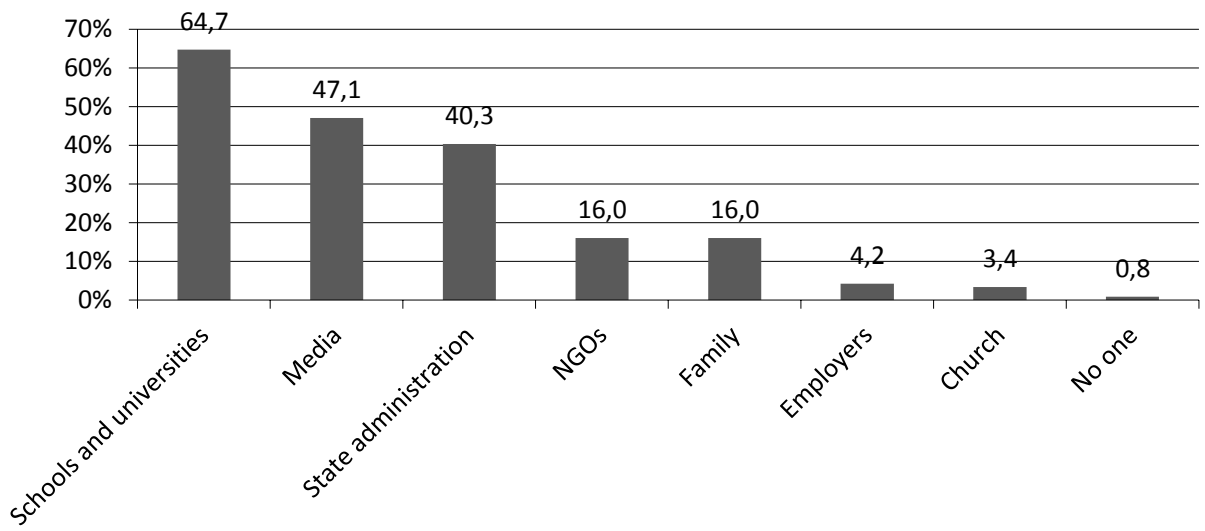

Figure 2. Entities responsible for disseminating knowledge about pro-ecological behaviours in the opinion of the respondents (more than one answer could be indicated)

Source: own research. 
appropriate use, while having practically no means of influencing the real activities of educated individuals. Such possibilities are available only to the state administration (the third most frequently indicated entity), which through legal coercion may impose specific solutions in the field of dealing with the natural environment. Unfortunately, a very worrying fact is the small weight attached by the respondents to family impact in the analysed scope, because it creates the first level of education, and many pro-ecological behaviours (e.g. saving resources, waste segregation, respect for nature) actually refer to a model of conduct carried out by young people from home, as a result of adaptation of actions taken by the first authorities - parents. Also surprises in such case the marginal role of such an opinion-forming institution as the denominational community.

The last element, which is worth devoting more attention in the context of environmental education, is the issue of how to disseminate knowledge about pro-ecological behaviours. Respondents' opinions in this topic are presented in Figure 3.

Among the answers received, two issues are worth noting. The first is the trust of young people in the effectiveness and scope of contemporary media and, at the same time, faith in their informative role, because they were first indicated as the subject which should take on the main burden of knowledge transfer in the discussed area, what confirms Nycz-Wróbel (2012) observations about significant role of mass media in shaping ecological awareness. At the same time, however, there can be expressed doubts about the interest of these media, operating mainly on market principles, in this type of activity. The second is the awareness of obligatory implementation of knowledge on this subject - this is consistent with observations of Tezel, Ugural and Giritli (2018), who claimed that education is an inseparable part of sustainable development, taking into account environmental problems. Also Vicente-Molina, Fernández-Sainz and Izagirre-Olaizola (2013) observed that formal education clearly influence pro-environmental behaviour, although the relation between those two aspects is complex and needs further research. Two other, most often indicated ways of disseminating information in the field of ecology, were methods based on coercion (school, law). Unfortunately, this may suggest the lack of a bottom-up will to transform and willingness to take certain behaviours, which is all the more surprising in the context of the group of respondents - students, and therefore the youth, which is associated with the change and in the future will be responsible for the decision-making process, also in the field of ecology.

\section{SUMMARY}

Undoubtedly, the surveyed students of the Faculty of Economic Sciences at the WULS-SGGW are aware of the need for pro-ecological behaviours, and their general awareness in this area indicates the proper formation of young people during their compulsory

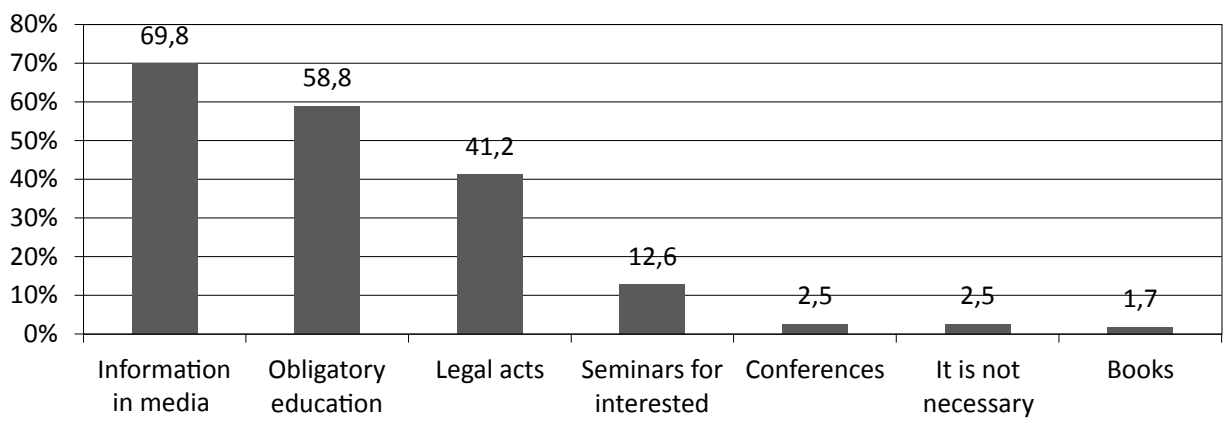

Figure 3. Ways of propagating knowledge about pro-ecological behaviours in the opinion of the respondents (more than one answer could be indicated)

Source: own research. 
education. Unfortunately, this does not result in the attitudes presented by them - the outcome of previous educational activities is only half of success, and it is only possible to confirm in the issue of self-determination of the respondents. However, the possible connections between such declaration and specific actions requires further research and exceeds the scope of this study. It is alarming that, despite the declared awareness, young people point to the necessity of coercion when implementing and promoting pro-ecological behaviours, while at the same time they relieve their closest social environment in the form of a family from this obligation. Unfortunately, this suggests that this model of thinking will be passed on to future generations, instilling an inertia and lack of personal responsibility in the field of environmental education in society, as - according to Vicente-Molina, Fernández-Sainz and Izagirre-Olaizola (2013) - today students will create future societies, thus the importance of their environmentally oriented education is crucial for progress toward sustainable development.

\section{REFERENCES}

1. Budniak, A. (2009). Edukacja społeczno-przyrodnicza dzieci w wieku przedszkolnym i młodszym szkolnym [Socio-natural education of children in pre-school and younger school]. Impuls, Kraków.

2. Budniak, A. (2014). Edukacja społeczno-przyrodnicza dzieci w wieku przedszkolnym i młodszym wieku szkolnym [Socio-natural education of children in preschool and younger school age]. Impuls, Kraków.

3. Dołega, J.M. (2003). Znaczenie nauk ekologicznych w ochronie środowiska i edukacji ekologicznej [The importance of ecological sciences in environmental protection and ecological education]. In: Z. Ciećko, J.M. Dołęga (eds.) Ochrona środowiska i edukacja ekologiczna w Unii Europejskiej i Polsce. Wydawnictwo Wszechnicy Mazurskiej, Olecko, p. 22.

4. Domeracki, P., Tyburski, W. (2011). Podstawy edukacji i kształtowania świadomości społecznej w duchu zrównoważonego rozwoju [The basics of education and shaping social awareness in the spirit of sustainable development]. In: W. Tryburski (ed.) Zasady kształtowania postaw sprzyjających wdrażaniu zrównoważonego rozwoju. Uniwersytet Mikołaja Kopernika, Toruń, pp. 244-245.
5. Egerton, F. (2013). History of Ecological Sciences. Part 47: Ernst Haeckel's Ecology. Bulletin of the Ecological Society of America, 94 (3), pp. 222-244.

6. Friederichs, K. (1958). A Definition of Ecology and Some Thoughts About Basic Concepts. Ecology. Ecological Society of America, 39 (1), pp. 154-159.

7. Górska, A. (1995). Wychowywać nowe społeczeństwo [Educating a new society]. Przyroda Polska, 11, p. 20.

8. Haeckel, E. (1866). Generelle Morphologie der Organismen. Allgemeine Grundzüge der organischen Formen-Wissenschaft, mechanische Begründet durch die von Charles Darwin reformirte Descendenz-Theorie. Vol. II: Alllgemeine Entwickelungsgeschichte der Organismen [General morphology of the organisms. General Principles of Organic Forms Science, Mechanical Founded by the descent theory reformulated by Charles Darwin. Vol. II: General evolutionary history of organisms]. Georg Reimer, Berlin.

9. Houszka, M. (2014). Ekologia i patologia [Ecology and pathology]. Życie Weterynaryjne, 89 (1), pp. 17-18.

10. Kiełczewski, D. (2001). Ekologia społeczna [Social ecology]. Ekonomia i Środowisko, Białystok.

11. Lozano, R. (2006). Incorporation and institutionalisation of SD into universities: breaking through barriers to change. Journal of Cleaner Production, 14 (9-11), pp. 787-796.

12. Nowińska, Z., Jarosz, W., Brol, J., Jarzębska, B., Przewoźnik, P. (2014). Postawa proekologiczna wyrazem troski o środowisko i własne zdrowie [Pro-ecological attitude as an expression of care for the environment and own health]. Instytut Ekologii Terenów Uprzemysłowionych w Katowicach, Katowice.

13. Nycz-Wróbel, J. (2012). Świadomość ekologiczna społeczeństwa i wynikające z niej zagrożenia środowiska naturalnego (na przykładzie opinii mieszkańców województwa podkarpackiego) [Ecological awareness of the society and the resulting threats to the natural environment (based on the opinion of the inhabitants of the Podkarpackie Voivodeship)]. Zeszyty Naukowe Politechniki Rzeszowskiej, 286. Ekonomia i Nauki Humanistyczne, 19 (3), pp. 63-76.

14. Papuziński, A. (2006). Świadomość ekologiczna w świetle teorii i praktyki (Zarys politologicznego modelu świadomości ekologicznej) [Ecological awareness in the light of theory and practice (Outline of the political model of ecological awareness)]. Problemy Ekorozwoju, 1 (1), pp. 33-40.

15. Parczewska, T. (2009). Edukacja ekologiczna w przedszkolu [Ecological education in kindergarten]. UMCS, Lublin. 
16. Sander, J. (2007). Idea zrównoważonego rozwoju w holistycznej edukacji przyrodniczej [The idea of sustainable development in holistic nature education]. Problemy Ekorozwoju, 2 (2), pp. 101-105.

17. Sander, J. (2008). Wybrane aspekty procesów środowiskowych holistycznej edukacji przyrodniczej w świetle idei zrównoważonego rozwoju [Selected aspects of environmental processes of holistic nature education in the light of the idea of sustainable development]. Problemy Ekorozwoju, 3 (2), pp. 69-80.

18. Sawitri, D., Widiaswati, D. (2018). Undergraduate students' pro-environmental behavior in daily practice. E3S Web of Conferences, 31, \# 09025.

19. Schlegelmilch, B.B., Bohlen, G.M., Diamantopoulos A. (1996). The link between green purchasing decisions and measures of environmental consciousness. European Journal of Marketing, 30 (5), pp. 35-55.

20. Strumińska-Doktór, A. (2007). Poziom wiedzy środowiskowej nauczycieli [Level of environmental knowledge of teachers]. In: D. Cichy (ed.) Edukacja środowiskowa w szkole i społeczności lokalnej. IBE, Warszawa, p. 123.

21. Terlecka, M.K. (2014). O edukacji ekologicznej w Polsce [About ecological education in Poland]. In: M.K. Terlecka (ed.) Edukacja ekologiczna. Wybrane problemy. Armagraf, Krosno, p. 9.

22. Tezel, E., Ugural, M., Giritli, H. (2018). Pro-environmental behavior of university students: influence of cultural differences. European Journal of Sustainable Development, 7 (4), pp. 43-52.

23. Tuszyńska, L. (2006). Edukacja ekologiczna dla nauczycieli i studentów [Ecological education for teachers and students]. WSP-TWP, Warszawa.

24. UNECE (2014). Strategy for Education for Sustainable Development. Retrieved: http://www.unece.org/fileadmin/DAM/env/esd/strategytext/strategyinPolish.pdf [Accessed 13.05.2019].

25. Vicente-Molina, M., Fernández-Sainz, A., Izagirre-Olaizola, J. (2013). Environmental knowledge and other variables affecting pro-environmental behaviour: Comparison of university students from emerging and advanced countries. Journal of Cleaner Production, 61, pp. $130-138$

26. WCED (1987). Our Common Future. Oxford University Press, Oxford.

27. Zelezny, L.C., Chua P-P., Aldrich Ch. (2000). Elaborating on gender differences in environmentalism. Journal of Social Issues, 56 (3), pp. 443-457.

28. Żeber-Dzikowska, I. (2016). Opinie nauczycieli dotyczące edukacji ekologicznej prowadzonej przez Regionalne Centrum Edukacji Ekologicznej w Płocku [Teachers' opinions on environmental education conducted by the Regional Center for Ecological Education in Płock]. Forum Pedagogiczne, 2 (2), pp. 123-143 . 